\title{
Valmiltistökur á Landspítala 1993-2004 Árangur og langtímaeftirfylgd
}

\author{
Margrét Jóna Einarsdóttir kandídat' ${ }^{1}$ Bergbór Björnsson læknir², Guðjón Birgisson læknir², \\ Vilhelmína Haraldsdóttir læknir³, Margrét Oddsdóttir læknir² + Lést 9. janúar 2009.
}

\section{ÁGRIP}

Tilgangur: Meta árangur valmiltistöku í meðferð blóðsjúkdóma. Meta tíðni fylgikvilla og kanna hvernig fræðslu og bólusetningum er háttað.

Efniviður og aðferðir: Farið var yfir sjúkraskrár peirra 67 sjúklinga sem gengust undir valmiltistöku á árunum 1993-2004. Spurningalistar voru sendir til 96\% (44/46) núlifandi sjúklinga, tveir fengu ekki spurningalista vegna búsetu erlendis.

Niðurstöður: Meðalaldur við aðgerð var 50 (8-83) ár. Karlar voru 35 og konur 32. Svörun spurningalista var 80\%.

Flestir sjúklinganna (31) voru með sjálfvakta blóðflögufæð (idiopathic thrombocytopenic purpura). Sextíu prósent peirra fengu fullan bata og $23 \%$ nokkurn bata. Fimm sjúklingar voru með hnattrauðkornablóðleysi (spherocytosis) og skilaði miltistaka fullum árangri hjá peim öllum. Prír sjúklingar voru með sjálfnæmisblóðleysi (autoimmune hemolytic anemia) en enginn peirra hlaut bata. Bólusett var gegn pneumókokkum i 92\% tilvika. Endurbólusetning fór fram hjá $44 \%$. Einungis $41 \%$ töldu sig hafa fengið góđa fræðslu um fylgikvilla miltisleysis.

Alvarlegir bráđir fylgikvillar komu fram hjá 16\% (10/64) sjúklinga. Einn sjúklingur með útbreitt krabbamein og blóðflögufæð lést innan 30 daga eftir aðgerð. Fimm sjúklingar fengu síðkomna fylgikvilla. Tveir fengu pneumókokkasýklasótt, annar var ekki bólusettur og hinn hafði ekki fengið endurbólusetningu á tilskildum tíma.

Ályktun: Miltistaka skilar góðum langtímaárangri hjá sjúklingum með blóðdílasótt og hnattrauðkornakvilla. Tíðni fylgikvilla er há. Vinnureglur um undirbúning, bólusetningar, eftirfylgd og fræðslu sjúklinga gætu fækkað fylgikvillum og bætt útkomu.

${ }^{1}$ Landspítala, Háskóla Íslands, ${ }^{2}$ skurðlækningadeild, ${ }^{3}$ blóđlækningadeild Landspítala.

\section{Fyrirspurnir:} Guðjón Birgisson gudjonbi@landspitali.is

Barst: 20. október 2010, sampykkt til birtingar: 2. mars 2011

Höfundar tiltaka hvorki styrki né hagsmunatengsl.

\section{Inngangur}

Miltistaka hefur lengi verið viðurkennd meðferð við ýmsum blóðsjúkdómum. ${ }^{1}$ Á seinni árum hefur miltistaka verið rannsökuð sem meðferðarúrræði, bæði við góðkynja og illkynja blóðsjúkdómum. Rannsóknir sýna misgóðan árangur af miltistöku eftir pví hvaða blóðsjúkdóm er verið að meðhöndla. Bestur árangur hefur náðst í meðferð hnattrauðkornablóðleysis (spherocytosis) par sem miltistaka skilar fullum árangri hjá nær öllum. ${ }^{2,3}$ Árangur miltistöku í meðferð sjálfvakinnar blóðflögufæðar (idiopathic thrombocytopenic purpura) hefur reynst lakari en tveir priðju sjúklinga fá fullan bata eftir miltistöku. ${ }^{2-4}$

Lengi vel var talið að hætta á sýklasótt eftir miltistöku (postsplenectomy sepsis) væri eingöngu barnasjúkdómur. ${ }^{5}$ Síðar var sýnt fram á að hættan er einnig til staðar hjá fullorðnum og hún varir ævilangt.6, 7 Áætlaðar líkur á pví að sá sem er miltislaus fái lífshættulega sýklasótt (overwhelming postsplenectomy infection) einhvern tíma á ævinni eru nærri 5\%. Dánartíðni peirra sem fá slíka sýkingu er mjög há, allt að 50\%.",8,9 Hjúpbakteríur á borð við pneumókokka (Streptococcus pneumoniae), meningókokka (Neisseria meningitidis) og Haemophilus influenzae eru sérstaklega hættulegar fyrir pá sem hafa ekki milta. ${ }^{6}$ Einnig hefur verið lýst aukinni hættu á blóðsýkingu af völdum annarra baktería, svo sem Escherichia Coli og streptókokka af tegund B. ${ }^{8}$

Í Bretlandi hafa verið gefnar út leiðbeiningar um ónæmisaðgerðir eftir miltistöku til að verja einstaklinga gegn lífshættulegum blóðsýkingum. ${ }^{10}$ Par er mikilvægi bólusetninga og fræðslu fyrir miltislausa gerð góð skil.
Mælt er með pneumókokkabólusetningu fyrir miltistöku og síðan á fimm ára fresti eftir pað. Að auki er mælt með bólusetningu gegn Haemophilus influenza týpu B og gegn meningókokkum týpu $C$ tveimur vikum fyrir eða tveimur vikum eftir miltistöku. Í leiðbeiningunum er einnig ráðlögð árleg inflúensubólusetning og mælt með pví að miltislausir fari til læknis um leið og sýkingareinkenni gera vart við sig. Раð er mismunandi eftir löndum hvort ráðlögð er fyrirbyggjandi sýklalyfjameðferð fyrir fullorðna miltislausa einstaklinga. ${ }^{10,11}$ Рó að leiðbeiningar liggi fyrir má ætla að peim sé ekki fylgt nógu vel eftir. Erlendar rannsóknir sýna að einungis priðjungur miltislausra sjúklinga hefur góða vitneskju um hugsanlegar afleiðingar miltisleysis og tveir priðju sjúklinga fái bólusetningu gegn pneumókokkum.12-14

Í byrjun tíunda áratugar síðustu aldar var farið að taka miltu með kviðsjártækni. ${ }^{2}$ Rannsóknir benda til að kviðsjáraðgerðir skili jafngóðum árangri við meðferð blóðsjúkdóma og opnar aðgerðir. 2, 3,15

Markmið pessarar rannsóknar var að kanna árangur valmiltistöku á Íslandi við meðferð blóðsjúkdóma og meta tíðni langtímafylgikvilla hjá pessum sjúklingahópi. Ekki var ætlunin að skoða bráða fylgikvilla sérstaklega. Skoða átti hvernig fræðslu og bólusetningum miltislausra væri háttað hér á landi.

\section{Efniviður og aðferðir}

Rannsóknin var að mestu leyti afturskyggn en einnig fengu sjúklingar sem voru á lífi spurningalista í pósti 
Tafla I. Yfirlit yfir rannsóknarhóp.

\begin{tabular}{lc}
\hline Fjöldi sjúklinga & 67 \\
\hline Karlar:Konur & $35: 32$ \\
\hline Meðalaldur við sjúkdómsgreiningu (ár) & $47(2-82)$ \\
\hline Meðalaldur við miltistöku (ár) & $50(8-83)$ \\
\hline Miðgildi aldurs við miltistöku (ár) & 54 \\
\hline Tími milli greiningar og miltistöku (mánuðir) & $33(0,2-259)$ \\
\hline Fjöldi sjúklinga á lifi pegar rannsókn er gerð & 46 \\
\hline Fjöldi sem fékk sendan spurningalista* & 44 \\
\hline Fjöldi peirra sem svaraði spurningalista & 35 \\
\hline
\end{tabular}

*21 einstaklingur var látinn pegar rannsóknin var gerð og tveir búsettir erlendis.

ásamt sampykkiseyðublaði. Rannsóknarhópurinn samanstóð af sjúklingum sem gengust undir valmiltistöku á Landspítala (bæði í Fossvogi og við Hringbraut) á tímabilinu 1.1.1993-31.12.2004. Valmiltistaka var skilgreind sem brottnám á milta sem var fyrirfram ákveðið sem valaðgerð. Undanskilin voru miltisnám sem áttu sér stað í öðrum aðgerðum, svo sem vegna áverka eða pegar milta var fjarlægt um leið og æxli í brisi eða maga. Upplýsingum var safnað úr sjúkraskrám peirra 67 sjúklinga sem uppfylltu áðurnefnd skilyrði. Einnig var farið yfir allar dánarorsakir peirra sjúklinga sem höfðu látist til að útiloka að dánarorsök peirra tengdist miltistökunni.

Spurningalistar voru sendir til sjúklinga sem voru á lífi pegar rannsóknin var gerð. Tveir voru búsettir erlendis og fengu af peim sökum ekki sendan spurningalista. Endanlegur fjöldi peirra sem fengu spurningalista var 44. Á spurningalistanum voru 12 krossaspurningar par sem spurt var um líðan eftir aðgerð, fræðslu, bólusetningar, viðbrögð við byrjandi sýkingareinkennum, sýklalyfjanotkun og núverandi eftirlit vegna pess sjúkdóms sem leiddi til miltistökunnar.

Árangur miltistöku var skilgreindur á sama hátt og í fyrri rannsóknum sem fullur bati, nokkur bati eða enginn bati. ${ }^{4}$ Við mat á bata sjúklinga eftir miltistöku purfti bati að hafa komið fram eftir miltistöku og haldast út pann eftirfylgdartíma sem rannsóknin náði yfir. Fullur bati hjá sjúklingum með sjálfvakta blóðflögufæð var skilgreindur sem blóðflögugildi yfir 150 x 109 / L án nokkurrar lyfjameðferðar. Nokkur bati var skilgreindur sem blóðflögugildi yfir 50 x 109 / L án lyfjameðferðar. Ef blóðflögugildi var undir 50 x $10^{9} / \mathrm{L}$ var pað metið sem enginn bati.

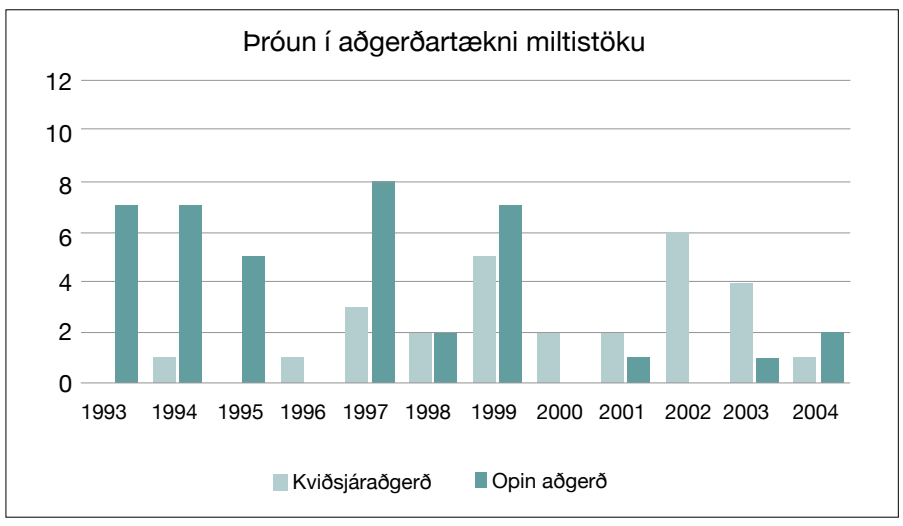

Mynd 1.
Fullur árangur hjá sjúklingum með hnattblóðkornakvilla og sjálfnæmisblóðleysi var skilgreindur sem blóðrauði yfir $134 \mathrm{~g} / \mathrm{L}$ fyrir karla og $118 \mathrm{~g} / \mathrm{L}$ fyrir konur, án blóðgjafa.

Ef blóðprufuniðurstöður sjúklings lágu ekki fyrir var fullur bati skilgreindur pannig að sjúklingur svaraði spurningalista á pá leið að hann væri hættur í öllu eftirliti vegna sjúkdómsins sem leiddi til miltistökunnar og líðan væri mun betri eftir miltistöku. Spurningalistar voru að öðru leyti ekki notaðir til að meta árangur miltistöku í meðferð blóðsjúkdóma.

Gagnabanki með ópersónugreinanlegum upplýsingum úr sjúkraskrám var búinn til í Microsoft Access. Gögnin voru færð inn í töflureikninn Microsoft Excel og framkvæmd var einföld tölfræðiúrvinnsla, ekki voru notuð tölfræðileg próf. Tilskilin leyfi fengust fyrir rannsókninni hjá Persónuvernd og siðanefnd Landspítala.

\section{Niðurstöður}

Á rannsóknartímabilinu voru framkvæmdar 67 valmiltistökur (tafla I). Meðalaldur sjúklinga við aðgerð var 50 ár (bil 8-83). Karlar voru 35 og konur 32. Eftirfylgd í rannsókninni var að meðaltali 60 mánuðir (bil 1-164) pegar miðað er við niðurstöður blóðrannsókna. Ekki náðist eftirfylgd með blóðprufum hjá sjö sjúklingum, prír af peim svöruðu hins vegar spurningalista. Eftirfylgd hvað varðar árangur miltistöku var pví engin hjá fjórum sjúklingum, prír af peim voru með illkynja sjúkdóma og einn með sjálfvakta blóðflögufæð.

Nokkrar sveiflur voru í fjölda aðgerða á pessu 12 ára tímabili. Flestar aðgerðir voru framkvæmdar árið 1999, eða 12 talsins, en einungis ein valmiltistaka var gerð árið 1996 (mynd 1).

Algengasta sjúkdómsgreining í rannsóknarhópnum var sjálfvakin blóðflögufæð og var 31 sjúklingur með pá greiningu. Fimm sjúklingar voru með hnattrauðkornablóðleysi, prír með sjálfnæmisblóðleysi (autoimmune hemolytic anemia), 19 með illkynja sjúkdóma og níu með aðra sjúkdóma sem ekki féllu undir hina flokkana (tafla II).

\section{Árangur i meðferð blóđsjúkdóma}

Af 31 sjúklingi með sjálfvakta blóðflögufæð voru 30 á barksterameðferð fyrir aðgerð og 17 á gammaglóbulínmeðferð. Bati var skilgreindur út frá blóðprufum í 29 tilvikum og út frá svörun spurningalista í einu tilviki par sem blóðprufuniðurstöður lágu ekki fyrir. Miltistaka skilaði fullum bata hjá 60\% (18/30), nokkrum bata hjá $23 \%(7 / 30)$ og engum bata hjá $17 \%$ (5/30) sjúklinga með sjálfvakta blóðflögufæð. Langtímaeftirfylgd náðist ekki hjá einum sjúklingi með sjálfvakta blóðflögufæð. Tveir sjúklingar sem eru flokkaðir með peim sem fengu fullan bata voru lengi að svara miltistökunni. Fullur bati fékkst hjá öðrum á 27 mánuðum en hjá hinum sex mánuðum eftir miltistöku. Einn sjúklingur fékk nokkurn bata fyrst eftir miltistökuna en síðan fullan bata sex árum síðar. Hann er engu að síður flokkaður með peim sem fengu nokkurn bata par sem ekki er hægt að segja til um hvort miltistakan eða eitthvað annað hafi valdið pví að fullur bati fékkst. Hlutfall kviðsjáraðgerða var $61 \%$ í hópnum sem hlaut fullan bata, $71 \%$ í hópnum með nokkurn bata og $40 \%$ í hópnum sem hlaut engan bata.

Fimm sjúklingar höfðu hnattrauðkornablóðleysi og náðist fullur árangur af miltistöku hjá peim öllum. Árangur var skilgreindur út frá blóðprufuniðurstöðum í fjórum tilvikum en í einu tilviki útfrá 
svörum spurningalista par sem blóðprufuniðurstöður lágu ekki fyrir.

Enginn peirra priggja með sjálfnæmisblóðleysi hlaut bata. Eftirfylgd með blóðprufum náðist hjá öllum premur sjúklingunum. Vert er að geta pess að einn pessara priggja sjúklinga fékk fullan bata fjórum árum eftir miltistökuna. Hann var samt sem áður flokkaður með peim sem fengu engan bata vegna pess hve batinn kom seint og ekki hægt að tryggja að hann væri tengdur miltistökunni.

Hjá sjúklingum með illkynja sjúkdóma var erfiðara að meta árangur par sem ábendingar miltistöku voru oft vegna einkenna fremur en til meðferðar á illkynja sjúkdóminum. Algengast var að milta væri fjarlægt vegna miltisstækkunar sem olli kviðverkjum (sjö sjúklingar), en einnig var algengt að milta væri tekið vegna meinvarps (fimm sjúklingar) eða til að bæta hag blóðfrumna (fjórir sjúklingar). Í tveimur tilvikum par sem átti að bæta fjölda blóðfrumna náðist tilætlaður árangur. Hvað varðar pau tilfelli pegar milta var tekið vegna kviðverkja hjá sjúklingum með illkynja sjúkdóma, var illa skráð í sjúkraskrár hvort verkir löguðust. Fjórir svöruðu spurningalista og svaraði einn af peim að honum liði betur eftir aðgerð. Pess ber að geta að pegar rannsóknin var gerð voru 68\% (13/19) sjúklinganna með illkynja sjúkdóm látnir.

\section{Niðurstöður spurningalista}

Spurningalistar voru sendir til 44 einstaklinga og af peim svöruðu 35. Раð vantaði svör við einstökum spurningum í 11 tilvikum. Sá sem sleppti flestum spurningum svaraði ekki premur spurningum.

Af peim sem svöruðu spurningalista töldu $41 \%$ sig hafa fengið góða fræðslu. Í einu tilviki var misræmi milli veittrar fræðslu og upplifunar sjúklings, pví sjúklingurinn hafði samkvæmt sjúkraskrá fengið sérstaka fræðslu frá smitsjúkdómalækni en svaraði spurningalista hins vegar á pá leið að hann hefði ekki fengið neina fræðslu frá heilbrigðisstarfsfólki. Um pað bil helmingur svarenda (47\%) kom fyrr til læknis vegna hita og slappleika eftir miltistöku, miðað við áður en miltað var fjarlægt. Sýklalyfjanotkun hafði aukist hjá $18 \%$ eftir miltistöku. Spurningu um hvort farið væri í árlega inflúensubólusetningu svöruðu 49\% játandi.

\section{Fyrirkomulag bólusetninga}

Fimm sjúklingar voru ekki bólusettir gegn pneumókokkum stuttu fyrir eða eftir miltistöku, hvorki samkvæmt sjúkraskrám né spurningalistum. Fyrir utan pessa fimm fannst ekki sjúkraskrá fyrir einn sjúkling sem fór í miltistöku árið 1993 og lést sama ár. Sjúklingar voru pví bólusettir gegn pneumókokkum í 92\% (61/66) tilvika. Bólusetningum fjölgaði eftir pví sem leið á rannsóknartímabilið. Peir fimm sjúklingar sem voru ekki bólusettir gegn pneumókokkum fóru í aðgerð á árunum 1993-1994. Pessar niðurstöður sýna að allir sjúklingar sem gengist hafa undir miltistöku 1995 eða síðar hafa verið bólusettir, að minnsta kosti gegn pneumókokkum.

Í rannsóknarhópnum áttu 32 sjúklingar að hafa fengið endurbólusetningu gegn pneumókokkum pegar rannsókn var gerð, pví meira en fimm ár voru liðin frá miltistöku. Endurbólusetning hafði verið gerð hjá 44\% (14/32) samkvæmt svörum við spurningalista og sjúkraskrám.

Fyrsti sjúklingurinn í rannsóknarhópnum sem var bólusettur gegn Haemophilus influenzae fór í miltistöku 1995. Árið 1997 var síðan fyrsti sjúklingurinn bólusettur gegn meningókokkum. Frá og með
Tafla II. Sjúkdómsgreiningar sem sjúklingarnir fengu eftir miltistöku. Sjúklingum var skipt í fimm flokka eftir sjúkdómsgreiningum.

\begin{tabular}{|c|c|c|}
\hline Sjúkdómsgreiningar & Fjöldi sjúklinga & Flokkaskipting \\
\hline Sjálfvakin blóðflögufæð & 30 & \multirow{2}{*}{$\begin{array}{c}\text { Sjálfvakin } \\
\text { blóðflögufæð }\end{array}$} \\
\hline Evans-heilkenni* & 1 & \\
\hline Hnattrauð̌kornakvilli (spherocytosis) & 5 & $\begin{array}{l}\text { Hnattrauð- } \\
\text { kornakvilli }\end{array}$ \\
\hline $\begin{array}{l}\text { Sjálfnæmisblóđleysi (autoimmune } \\
\text { hemolytic anemia) }\end{array}$ & 3 & $\begin{array}{c}\text { Sjálfnæmis- } \\
\text { blóðleysi (AlHA) }\end{array}$ \\
\hline Eitilfrumuæxli (lymphoma) & 9 & \multirow{5}{*}{$\begin{array}{l}\text { Illkynja } \\
\text { sjúkdómar }\end{array}$} \\
\hline Hvítblæði (leukemia) & 3 & \\
\hline Meinvörp í milta & 5 & \\
\hline $\begin{array}{l}\text { Mergmisproskun (myelodysplastic } \\
\text { syndrome) }\end{array}$ & 1 & \\
\hline $\begin{array}{l}\text { Mergfrumnafjölgun (myeloproliferative } \\
\text { syndrome) }\end{array}$ & 1 & \\
\hline Miltisstækkun & 3 & \multirow{6}{*}{ Ađrir sjúkdómar } \\
\hline Blóðæðaæxli (hemangioma) & 2 & \\
\hline Miltisblaðra & 1 & \\
\hline Feltys-heilkenni & 1 & \\
\hline $\begin{array}{l}\text { Blóðflögufæð í tengslum við rauða úlfa } \\
\text { (Systemic Lupus Erythematosus) }\end{array}$ & 1 & \\
\hline Sjálfsofnæmissjúkdómur í milta & 1 & \\
\hline
\end{tabular}

*Sjúklingurinn með Evans-heilkenni sýndi meiri einkenni sjálfvakinnar blóðflögufæðar en sjálfnæmisblóðleysis og er pví flokkaður með sjúklingum með sjálfvakna blóðflögufæð.

árinu 1998 hafa 54\% verið bólusettir annaðhvort gegn Haemophilus influenzae týpu B eða meningókokkum, ásamt pneumókokkabólusetningu. Frá og með árinu 1998 hafa 43\% sjúklinga fengið allar prjár bólusetningarnar.

\section{Aðgerðartækni og brádir fylgikvillar}

Af peim 67 miltistökum sem voru framkvæmdar voru 27 kviðsjáraðgerðir. Premur af pessum 27 var breytt í opna aðgerð, í tveimur tilvikum vegna blæðingar en í einu tilviki var ástæðan ekki skráð. Alvarlegir bráðir fylgikvillar komu fram hjá 16\% (10/64) sjúklinga. Upplýsingar um bráđa fylgikvilla vantaði í premur tilvikum. Einn sjúklingur með útbreitt lungnakrabbamein og blóðflögufæð lést vegna blæðingar í kvið innan sólarhrings frá aðgerð. Fjórir sjúklingar fengu neðanpindarígerð, tveir alvarlegar blæðingar eftir aðgerð, tveir heilablóðfall, einn pindarrof og tveir lungnarek. Í tveimur tilvikum fengu sjúklingar tvo bráða fylgikvilla.

\section{Langtímafylgikvillar}

Langtímafylgikvillar miltistöku komu fram hjá fimm sjúklingum. Prír sjúklingar fengu sýklasótt (sepsis), einn fékk skurðarhaul (incisional hernia) og einn purfti að gangast undir samvaxtalosun 10 árum eftir miltistöku.

Tvær sýklasóttir voru af völdum pneumókokka. Í hvorugu tilfellinu purfti sjúklingur að liggja á gjörgæslu. Annað tilfellið varð ári eftir miltistöku og hafði sá sjúklingur ekki fengið pneumókokkabólusetningu. Sú sýklasótt var af völdum hjúpgerðar 23 en hjúpgerðin var ekki undirflokkuð frekar pannig að ekki er hægt að segja til um hvort að pneumókokkabóluefni hefði veitt vörn. Hitt tilfellið af pneumókokkasýklasótt var hjá einstaklingi 
sex árum eftir miltistöku. Sá var bólusettur pegar miltistakan var framkvæmd. Ekki fundust nein gögn um að hann hefði fengið endurbólusetningu. Orsök sýklasóttarinnar voru pneumókokkar af hjúpgerð 7F en pneumókokkabóluefnið á að veita vörn gegn peirri hjúpgerð.

Einn sjúklingur fékk alvarlega sýklasótt vegna streptókokka af tegund B, tveimur árum eftir miltistöku sem var framkvæmd vegna sjálfvakinnar blóðflögufæðar. Sjúklingurinn fór í lost, fékk dreifða blóðstorknun (disseminated intravascular coagulation), bráða nýrnabilun, andnauðarheilkenni (adult respiratory distress syndrome) og lá prjár vikur á gjörgæslu. Enginn pessara fimm sjúklinga sem fengu síðkomna fylgikvilla lést af peirra völdum.

Pegar tíðni sýklasóttar í rannsókninni er reiknuð á hver 100 sjúklingaár var tíðnin 1,03 á hver 100 sjúklingaár.

\section{Umræður}

Niðurstöður pessarar rannsóknar eru í nokkuð góðu samræmi við erlendar rannsóknir. Stór safngreining (meta-analysis) frá árinu 2004 tók saman niðurstöður úr 47 greinum frá árunum 1966-2004 sem fundust við leit á Medline. Niðurstöður peirrar greiningar sýna að $66 \%$ sjúklinga með sjálfvakta blóðflögufæð fá fullan bata. ${ }^{4}$ Mögulega er hlutfall peirra sem fá fullan bata aðeins lægra í pessari rannsókn vegna pess hve ströng skilgreining svörunar var. Í sumum rannsóknum er fullur bati skilgreindur sem blóðflögugildi yfir 100 x $10^{9}$ /L eða yfir $120 \times 10^{9}$ / Lán lyfjameðferðar., ${ }^{4,15}$ Safngreiningin frá 2004 gerði ekki greinarmun á pví hvort svörun væri skilgreind yfir $100 \times 10^{9}$ /L eða yfir $150 \times 10^{9}$ / L í greinunum sem hún tók saman og pví er hlutfall fulls bata líklega eitthvað hærra en ef einungis hefðu verið teknar saman greinar sem skilgreindu fullan bata líkt og gert var í pessari rannsókn. Ef fullur bati af sjálfvakinni blóðflögufæð hefði verið skilgreindur sem blóðflögur yfir $100 \times 10^{9}$ /L í pessari rannsókn hefði samtals 21 sjúklingur verið talinn hafa hlotið fullan bata, eða $70 \%(21 / 30)$.

Fullkominn árangur af miltistöku meðal sjúklinga með hnattrauðkornakvilla er vel pekktur., ${ }^{2}$ Hins vegar er árangur slæmur hjá sjúklingum með sjálfnæmisblóðleysi samanborið við aðrar rannsóknir, sem sýna um 66-70\% líkur á bata. ${ }^{2,3}$ Erfitt er að draga of miklar ályktanir af pessu par sem einungis prír sjúklingar voru með pessa greiningu.

Tíðni síðkominna fylgikvilla er 7,5\% og mætti eflaust lækka pá tíðni enn frekar með endurbólusetningum og fræðslu. Algengasti síðkomni fylgikvillinn var sýklasótt og var tíðni sýklasóttar eftir miltistöku 1,03 á hver 100 sjúklingaár. Erlendar rannsóknir sýna mun lægri tíðni, eða 0,18-0,42 á hver 100 sjúklingaár. ${ }^{16,17}$ Pær rannsóknir skoða ekki sambærilegan sjúklingahóp pví í rannsóknarhópum peirra eru einnig sjúklingar sem fara í miltistöku í kjölfar áverka en vitað er að tíðni sýklasótta, hjá peim hópi er lægri en hjá sjúklingum með blóðsjúkdóma. ${ }^{6}$ Einnig fylgja pessar rannsóknir sjúklingunum eftir í mun lengri tíma og reikna sína tíðni út frá hverjum 100 sjúklingaárum. Tíðni sýklasóttar er hæst fyrst eftir miltistöku og er tíðni mæld á hver 100 sjúklingaár pví hæst pegar eftirfylgdin er stutt. ${ }^{8}$ Vegna pessa eru pessar tíðnitölur ekki sambærilegar og pví er ekki unnt að álykta að tíðni sýklasóttar meðal miltislausra sé hærri á Íslandi en annars staðar.
Líklega er fræðsla frá heilbrigðisstarfsmönnum ekki jafnlítil og niðurstöður pessarar rannsóknar gefa til kynna. Rannsóknir sýna að sjúklingar muna marktækt betur pær upplýsingar sem peir fá skriflega. ${ }^{18}$ Рað væri pví ekki úr vegi að gefa út bækling fyrir miltislausa um mögulegar hættur og æskilegar forvarnir, líkt og mælt hefur verið með í klínískum leiðbeiningum í Bretlandi. ${ }^{10}$ Mikilvægi fræðslu endurspeglast enn frekar í pví að pað hefur verið sýnt fram á að góð fræðsla miltislausra skili sér í marktækt lægri tíðni alvarlegra sýklasótta. ${ }^{19}$ Ástandið hér á landi er svipað og erlendis pegar horft er á fræðslu miltislausra um mögulegar afleiðingar miltisleysis. Írsk rannsókn frá 2006 sýndi að um priðjungur sjúklinga fær fræðslu um fylgikvilla miltisleysis. ${ }^{12}$

Frumbólusetningar virðast vera í góðum farvegi hér á landi. Niðurstöður breskrar rannsóknar frá árinu 2003 og danskrar rannsóknar frá árinu 2000 benda til að hlutfall peirra sem fá frumbólusetningu við miltistöku sé hátt hérlendis. Samkvæmt dönsku rannsókninni fengu $60 \%$ sjúklinga sem fóru í miltistöku bólusetningu gegn pneumókokkum og 72\% samkvæmt bresku rannsókninni. ${ }^{13,14}$

Til að bæta forvarnir enn frekar mætti skoða hver ætti að sjá um endurbólusetningar hjá peim sem fara í valmiltistöku, sérstaklega hjá peim hópi sem fær fullan bata eftir miltistöku og hættir par af leiðandi snemma í reglubundnu eftirliti hjá sérfræðingum í blóðsjúkdómum.

Einn af kostum pessarar rannsóknar er að á Landspítala eru nánast allar valmiltistökur landsins framkvæmdar. Nýlega var gerð úttekt á miltistökum á Fjórðungssjúkrahúsinu á Akureyri á árunum 1985-2006. Engin miltistaka í peirri rannsókn hefði uppfyllt skilmerki pessarar rannsóknar á pví rannsóknartímabili sem við lögðum upp með. ${ }^{20}$ Pað má pví segja að pótt pessi rannsókn sé ekki viðamikil gefi hún samt skýra mynd af valmiltistökum á Íslandi.

Gallar rannsóknarinnar eru nokkrir. Рað er erfitt að gera afturskyggna rannsókn sem nær svo langt aftur í tímann. Eins og má sjá á niðurstöðunum lágu ekki fyrir upplýsingar um alla sjúklinga hvað varðar alla pætti. Ákjósanlegast hefði verið að eftirfylgd með blóðprufuniðurstöðum hefði náðst hjá öllum sjúklingum. Rannsóknarhópurinn var hins vegar lítill og pví ekki hægt að minnka hann enn frekar með pví að taka einungis með í rannsóknina pá sjúklinga sem allar upplýsinga lágu fyrir um. Sú leið var pví farin að nota pær upplýsingar sem lágu fyrir hverju sinni. Smæð hópsins takmarkar einnig tölfræðilega úrvinnslu. En prátt fyrir gallana má draga pær ályktanir að margt sé hægt að gera betur í fræðslu og sýkingarforvörnum miltislausra. Einnig má draga pær ályktanir að miltistaka skili góðum langtímaárangri hjá sjúklingum með sjálfvakna blóðflögufæð og hnattrauðkornakvilla.

\section{Pakkir}

Pakkir fá læknarnir Guðmundur I. Eyjólfsson, Shree Datye og Jóhannes Björnsson. Einnig fá Sigríður P. Skúladóttir læknaritari, Ólöf Garðarsdóttir deildarstjóri hjá Hagstofunni, starfsfólk bókasafns Landspítala og læknaritarar skurðdeildar Landspítala Hringbraut bestu pakkir. 


\section{Heimildir}

1. Sutherland G. The Treatment of Splenic Anæmia by Splenectomy. Lancet 1910; 176: 1819-22.

2. Tanoue $\mathrm{K}$, Okita $\mathrm{K}$, Akahoshi T, et al. Laparoscopic splenectomy for hematologic diseases. Surgery 2002; 131(1 Suppl): S318-23.

3. Balagué C, Targarona EM, Cerdán G, et al. Long-term outcome after laparoscopic splenectomy related to hematologic diagnosis. Surg Endosc 2004; 18: 1283-7.

4. Kojouri K, Vesely SK, Terrell DR, George JN. Splenectomy for adult patients with idiopathic thrombocytopenic purpura: a systematic review to assess long-term platele count responses, prediction of response, and surgical complications. Blood 2004; 104: 2623-34.

5. King H, Shumacker HB, Jr. Splenic Studies. I. Susceptibility to infection after splenectomy performed in infancy. Ann Surg 1952; 136: 239-42.

6. Singer DB. Postsplenectomy Sepsis. Perspect Pediatr Pathol 1973; 1: 285-311.

7. O'Neal BJ, McDonald JC. The Risk of Sepsis in the Asplenic Adult. Ann Surg 1981; 194: 775-8.

8. Lynch AM, Kapila R. Overwhelming Postsplenectomy Infection. Infect Dis Clin North Am 1996; 10: 693-707.
9. Waghorn DJ, Mayon-White RT. A study of 42 episodes of overwhelming post-splenectomy infection: is current guidance for asplenic individuals being followed? J Infect 1997; 35: 289-94.

10. Davies JM, Barnes R, Milligan D. Update of guidelines for the prevention and treatment of infection in patients with an absent or dysfunctional spleen. Clin Med 2002; 2: 440-3.

11. Brigden ML. Detection, Education and Management of the Asplenic or Hyposplenic patient. Am Fam Physician 2001 63: 499-506.

12. Hegarty PK, Tan B, O'Sullivan R, Cronin CC, Brady MP Prevention of postsplenectomy sepsis: how much do patients know? Hematol J 2000; 1: 357-9.

13. Ejstrud P, Kristensen B, Hansen JB, Madsen KM, Schønheyder HC, Sørensen HT. Risk and Patterns of Bacteraemia after Splenectomy: a Population-Based Study. Scand J Infect Dis 2000; 32: 521-5.

14. Ramachandra J, Bond A, Ranaboldo C, Cullis J. An audit of post-splenectomy prophylaxis--are we following the guidelines? Ann R Coll Surg Engl 2003; 85: 252-5.
15. Berends FJ, Schep N, Cuesta MA, et al. Hematological long-term results of laparoscopic splenectomy for patients with idiopathic thrombocytopenic purpura. A case contro study. Surg Endosc 2004; 18: 766-70.

16. Schwartz PE, Sterioff S, Mucha P, Melton LJ 3rd, Offord KP. Postsplenectomy sepsis and mortality in adults. JAMA 1982; 248: 2279-83.

17. Cullingford GL, Watkins DN, Watts AD, Mallon DF. Severe late postsplenectomy infection. Br J Surg 1991; 78: 716-21.

18. Mauffrey C, Prempeh EM, John J, Vasario G. The influence of written information during the consenting process on patients' recall of operative risks. A prospective randomised study. Int Orthop 2008; 32: 425-9.

19. El-Alfy MS, El-Sayed MH. Overwhelming postsplenectomy infection: is quality of patient knowledge enough for prevention? Hematol J 2004; 5: 77-80.

20. Gunnarsdóttir J, Datye SS. Ábendingar miltisbrottnáms á FSA á tímabilinu 1985-2006. Læknablaðið 2007; 93: 330-1.

\section{ENGLISH SUMMARY}

\section{Elective Splenectomy at Landspitali University Hospital 1993-2004 Efficacy and Long-Term Outcome}

Einarsdottir MJ, Björnsson B, Birgisson G, Haraldsdottir V, Oddsdottir M

Objective: To evaluate the long-term outcome of elective splenectomy, with emphasis on the incidence of complications, vaccine immunization and patient's knowledge about asplenia.

Material and methods: Medical reports of all patients, who underwent elective splenectomy during the time period of 1993-2004, were reviewed. Questionnaire was sent to $96 \%$ (44/46) patients alive.

Results: The average age was 50 (8-83) years. Thirty-five patients were male and 32 were female. Eighty percent responded to the questionnaire. Most of the patients (31) had idiopathic thrombocytopenic purpura (ITP). Complete response was obtained in 60\% (18/30) and partial response in $23 \%$ (7/30). Five patients had spherocytosis and all of them had complete response. None of the three patients with autoimmune hemolytic anemia had any response to the splenectomy. Patients were vaccinated against pneumococci in $92 \%$ of the cases. In $44 \%$ of the cases revaccination was done. Only $41 \%$ of those who answered experienced that they had got a good education about the consequences of asplenia. Sixteen percent of the patients (10/64) had major postoperative complications. One patient with metastatic cancer and thrombocytopenia died within 30 days of surgery. Five patients had long-term complications. Two had pneumococcal sepsis, one of them was unvaccinated and the other had not been revaccinated.

Conclusion: Splenectomy has a good long-term outcome for spherocytosis and ITP patients. The incidence of complications is high. It is possible that better guidelines and better patient's education can lower the complication rate and improve the outcome.

Key words: splenectomy, vaccination, postsplenectomy sepsis, idiopathic thrombocytopenic purpura, spherocytosis.

Correspondence: Guðjón Birgisson, gudjonbi@landspitali.is 